\section{Amyotrophic Lateral Sclerosis: From Disease Mechanisms to Therapies}

\author{
Lucie I. Bruijn \\ The Amyotrophic Lateral Sclerosis \\ Association, Guilford, CT, USA
}

\section{INTRODUCTION}

Amyotrophic lateral sclerosis (ALS) or Lou Gehrig's disease is the most common motor neuron disease in human adults, described as early as 1869 by a French neurobiologist and physician, Jean-Martin Charcot. Although advances in genetics have accelerated the pace of ALS research in the past decade, there is currently only one FDA-approved compound (Riluzole) to treat the disease, a compound that shows very modest effects in patients with ALS. Since ALS affects only 60000 individuals worldwide at a given time, it is not as attractive a disorder for pharmaceutical investment as are atherosclerosis, depression, or cancer. The complexities of drug discovery, development, and registration require the resources of a large company to develop new therapies. An increased understanding of disease mechanism in neurodegenerative disorders and identification of drug targets through academic efforts will help to drive drug development in the pharmaceutical industry forward and necessitates collaborative efforts between the two sectors. This column will illustrate that ALS is potentially a useful model for more common neurodegenerative disorders such as Alzheimer's and Parkinson's disease and may indeed be more amenable for drug development. Lessons learned in the treatment of ALS may provide information useful in other neurodegenerative disorders in which sim ilar cell death pathways may be afflicted.

\section{CLINICAL AND PATHOLOGICAL FEATURES OF ALS}

The primary hallmark of the disease is the selective loss of motor neurons in the brain and spinal cord. This loss leads to progressive atrophy of skeletal muscles, resulting in the decline of muscle function and paralysis (47). Denervation of the respiratory muscles and diaphragm is generally the fatal event that occurs within $1-5$ years of onset. The typical age of onset for most sporadic and familial forms occurs between 50 and 60 years and has a prevalence of 2-3 per 100000 . At any one time, 30000 individuals in the USA and 5000 in the UK are affected by ALS. Of the total cases, 5\%-10\% are inherited (familial); however, the majority of ALS cases have no genetic component (sporadic). The clinical course is very variable among patients with either familial or sporadic ALS, leading investigators to believe that there are likely multiple factors underlying the disease mechanism.

\section{UNDERSTANDING THE DISEASE MECHANISM OF ALS}

The drug discovery process (37) involves the identification of targets, either hypothesis-driven or more recently through bioinformatics. Those targets that are well defined and validated are more likely to lead to successful compounds. Over the years, many hypotheses for mechanisms underlying the selective killing of motor neurons in ALS have been proposed (for recent reviews, see References 17 and 39) and include oxidative damage, copper toxicity, abnormal protein accumulations, excitotoxicity, inflammation, apoptosis, and mitochondrial damage. Current drugs in development for ALS are based on some of these hypotheses (Table 1). Similar mechanisms have been proposed for Alzheimer's, Parkinson's, and Huntington's disease $(21,57,67)$, all adult-onset disorders, although the initial insult and cell types involved differ.

Accumulations of neurofilaments in cell bodies and axons of motor neurons in both sporadic (31) and familial (32) ALS have been considered as the hallmark of the disease. Abnormal expression of neurofilaments in mouse models leads to motor neuron degeneration, which is a strong argument for their direct involvement in the disease (20). Mutations in neurofilaments linked to familial ALS have not been identified; however, a set of in-frame deletions and insertions has been identified in sporadic ALS, supporting the idea that neurofilaments are risk factors for the disease (1). Mutations in a ubiquitously expressed protein $\mathrm{Cu} / \mathrm{Zn}$ superoxide dismutase (SOD1), linked to $20 \%$ of familial ALS, were discovered in 1993 (54). These mutations provided the first definitive cause of motor neuron death and led to the development of animal models that most closely mimic the human disease (13, 26,53,63). Unlike the more limited models of Alzheimer's (36) and Huntington's (6) disease, mice carrying different mutant forms of human SOD1 demonstrate a robust phenotype of neurodegeneration. The mutant enzyme is ubiquitously expressed (under control of the human endogenous promoter) at levels equal to or several-fold higher than the level of endogenous SOD1. Transgenic mice develop hind-limb weakness at 3-8 months depending on the SOD1 mutation (there are now more than 90 different point mutations linked to familial ALS). Hind-limb weakness coincides with increased astrogliosis, activation of microglia, and loss of motor neurons. These mouse models have been invaluable for testing disease hypotheses and therapeutic approaches (Table 1).

\section{Oxidative Damage, Nitration, and Copper Toxicity}

It is well established in the field that SOD1-mediated toxicity in ALS is not due to loss of function but likely the gain of a new aberrant property. SOD1 null mice (51) do not develop motor neuron disease; none of the mutations eliminate the synthesis of a full-length protein, and some mutants retain full specific activity (10). What is less clear is the nature of this aberrant property. Several in vitro studies propose abnormal folding of SOD1, exposing the 
Table 1. Representation of Compounds Tested for Treatment of ALS: Studies in Transgenic Mice and Human Clinical Trials

\begin{tabular}{|c|c|c|c|c|}
\hline $\begin{array}{l}\text { Compound } \\
\text { Description }\end{array}$ & $\begin{array}{l}\text { SOD1G93ATransgenic } \\
\text { Mouse Models of ALS }\end{array}$ & $\begin{array}{l}\text { ALS Clinical } \\
\text { Trials }\end{array}$ & Comment & References \\
\hline Antioxidant & $\begin{array}{l}\text { SOD1, catalase, } \\
\text { vitamin E, } \\
\text { carboxyfullerenes }\end{array}$ & Vitamin E & $\begin{array}{l}\text { Vitamin E was not efficacious in ALS } \\
\text { patients. SOD1 and catalase mimetic } \\
\text { resulted in } 10 \% \text { extension in lifespan } \\
\text { in mouse model. }\end{array}$ & $22,27,52$ \\
\hline $\begin{array}{l}\text { Copper } \\
\text { chelator }\end{array}$ & $d$-penicillamine & & $\begin{array}{l}8 \% \text { extension in lifespan } \\
\text { in mouse model. }\end{array}$ & 34 \\
\hline $\begin{array}{l}\text { Anti- } \\
\text { inflammatory }\end{array}$ & $\begin{array}{l}\text { Cyclosporin, aspirin, } \\
\text { indomethacin, COX-2 } \\
\text { inhibitor }\end{array}$ & $\begin{array}{l}\text { COX-2 } \\
\text { inhibitor }\end{array}$ & $\begin{array}{l}\text { COX-2 inhibitor currently in human } \\
\text { clinical trials. These inhibitors are also } \\
\text { being tested in Alzheimer's disease. }\end{array}$ & 66 \\
\hline Anti-apoptosis & zVAD-fmk & & $\begin{array}{l}\text { Broad-spectrum caspase inhibitor } \\
\text { zVAD-fmk extended lifespan by } 25 \% \text {. } \\
\text { Too toxic for human clinical trials. }\end{array}$ & 44 \\
\hline $\begin{array}{l}\text { Calcium } \\
\text { regulation }\end{array}$ & Calbindin & $\begin{array}{l}\text { Verapamil, } \\
\text { nimodepine }\end{array}$ & None efficacious & 45,46 \\
\hline Anti-glutamate & Riluzole & Riluzole & $\begin{array}{l}\text { Riluzole had a modest effect at } \\
\text { increasing survival in ALS patients in } \\
\text { two independent trials. In mice, survival } \\
\text { was extended by } 10 \% \text {. }\end{array}$ & $27,28,44$ \\
\hline $\begin{array}{l}\text { Energy } \\
\text { metabolism }\end{array}$ & Creatine & Creatine & $\begin{array}{l}\text { Human clinical trial in progress. Increased } \\
\text { survival by } 18 \% \text { in mouse model. }\end{array}$ & 40 \\
\hline Trophic factors & BDNF, GDNF, BMP7 & $\begin{array}{l}\text { CNTF, BDNF, } \\
\text { GDNF, xalipro- } \\
\text { den IGF-1 }\end{array}$ & $\begin{array}{l}\text { IGF-1 showed modest effect in US trials } \\
\text { and no effect in European trial. A new } \\
\text { trial will begin in US shortly with } \\
\text { improved endpoint markers. }\end{array}$ & 62,64 \\
\hline
\end{tabular}

active copper and zinc binding site. This may enable aberrant chemical reactions such as the formation of peroxynitrite, leading to nitration of tyrosine residues (9). Evidence for this reaction playing a major role in motor neuron death in vivo is less compelling (12). Although copper is thought to play a role in SOD1-mediated toxicity, studies using transgenic mice indicate that it is unlikely to be a key contributor to SOD1-mediated cell death. Dramatically lowering copper loading onto mutant SOD1 in transgenic mice does not change onset, disease progression, or survival (60). Mitochondrial degeneration has been implicated in several neurodegenerative disorders $(7,8)$. In transgenic mice expressing mutant SOD1, mitochondrial damage is seen early in the disease (41). Mutant $\mathrm{Cu} / \mathrm{Zn}$ SOD1 is present in the inner membrane space of mitochondria (30) and may play a direct toxic role. Creatine, which enhances energy storage capacity and inhibits the opening of the mitochondrial transition pore (which is thought to play an important role in mitochondrial degeneration), prolongs the lifespan of transgenic SOD1 mice and is currently in clinical trials for ALS (Table 1).

\section{Abnormal Protein Aggregation}

The presence of abnormal protein aggregates or inclu- sions has been described in many neurodegenerative diseases. Efforts to design strategies to block these abnormal accumulations in Alzheimer's (58), Parkinson's (18), Huntington's disease (59), and ALS are in progress. In transgenic mice expressing mutant SOD1G85R (15), abnormal protein accumulations, detected by hematoxylinand-eosin staining (Figure 1A), appear before the onset of hind-limb weakness and are found in both astrocytes (Figure 1B) and neurons. These accumulations are highly im munoreactive for SOD1 (Figure 1C). Whether these aggregates are integrally involved in the disease process or beneficial in sequestering toxic byproducts remains to be determined. Misfolded SOD1 aggregates cannot be readily dissociated and can be detected biochemically in transgenic SOD1 mice long before disease develops $(38,61)$.

\section{Excitotoxicity}

Glutamate-mediated excitotoxicity from repetitive firing and/or elevation of intracellular calcium has long been implicated in neuronal death. Evidence for the role of glutamate in ALS came from early studies showing increased levels of glutamate in cerebrospinal fluid of ALS patients (56). One of the functions of the compound Riluzole is to inhibit glutamate release. The main glutamate 


\section{DRUG DISCOVERY \\ AN D GENOMIC TECHNOLOGIES}

transporter for the removal of excess synaptic glutamate (EAAT2) is decreased in ALS patient samples (55), which provides further evidence for the role of glutamate toxicity in the disease. Expression of SOD1 mutants in transgenic mice (14) and rats (35) leads to a decrease in the EAAT2 coincident with disease onset. Strategies to up-regulate EAAT2 expression may provide an important approach for treating ALS.

\section{Other Targets for ALS}

Additional targets for ALS include caspases 1 and 3 (23, 42,50), cyclin-dependent kinase (cdk5), and the calpain cleavage product of $\mathrm{p} 35$ (the neuronal-specific activator for cdk5), p25, which was recently implicated in abnormal phosphorylation of tau in Alzheimer's disease (48) and vascular endothelial growth factor (VEGF) (49). Targeted

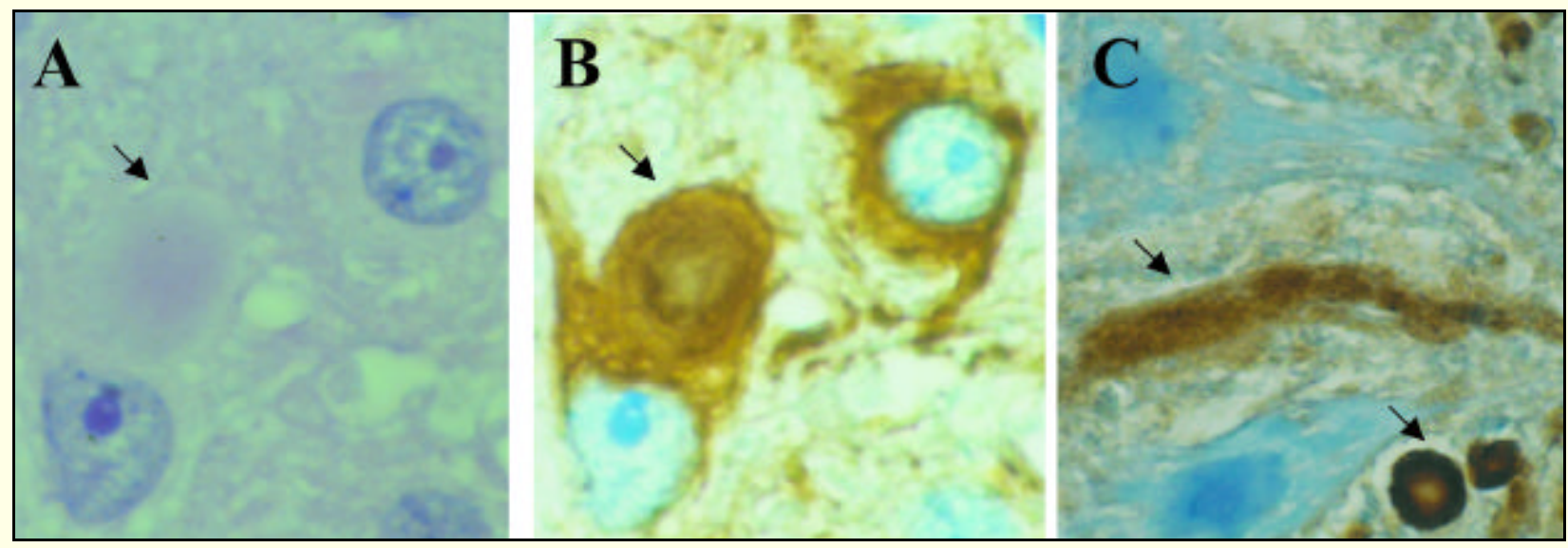

Figure 1. Abnormal aggregates detected early in transgenic mice expressing mutant SOD1 $\mathrm{Gr5R}$ and increase in abundance at end-stage disease. (A) Inclusions detected by hematoxylin-and-eosin staining (arrow) of a spinal cord cross section are present in (B) astrocytes (arrow), as determined by GFAP reactivity and neurons. These inclusions are highly immunoreactive for (C) Cu/Zn SOD1 (arrows).

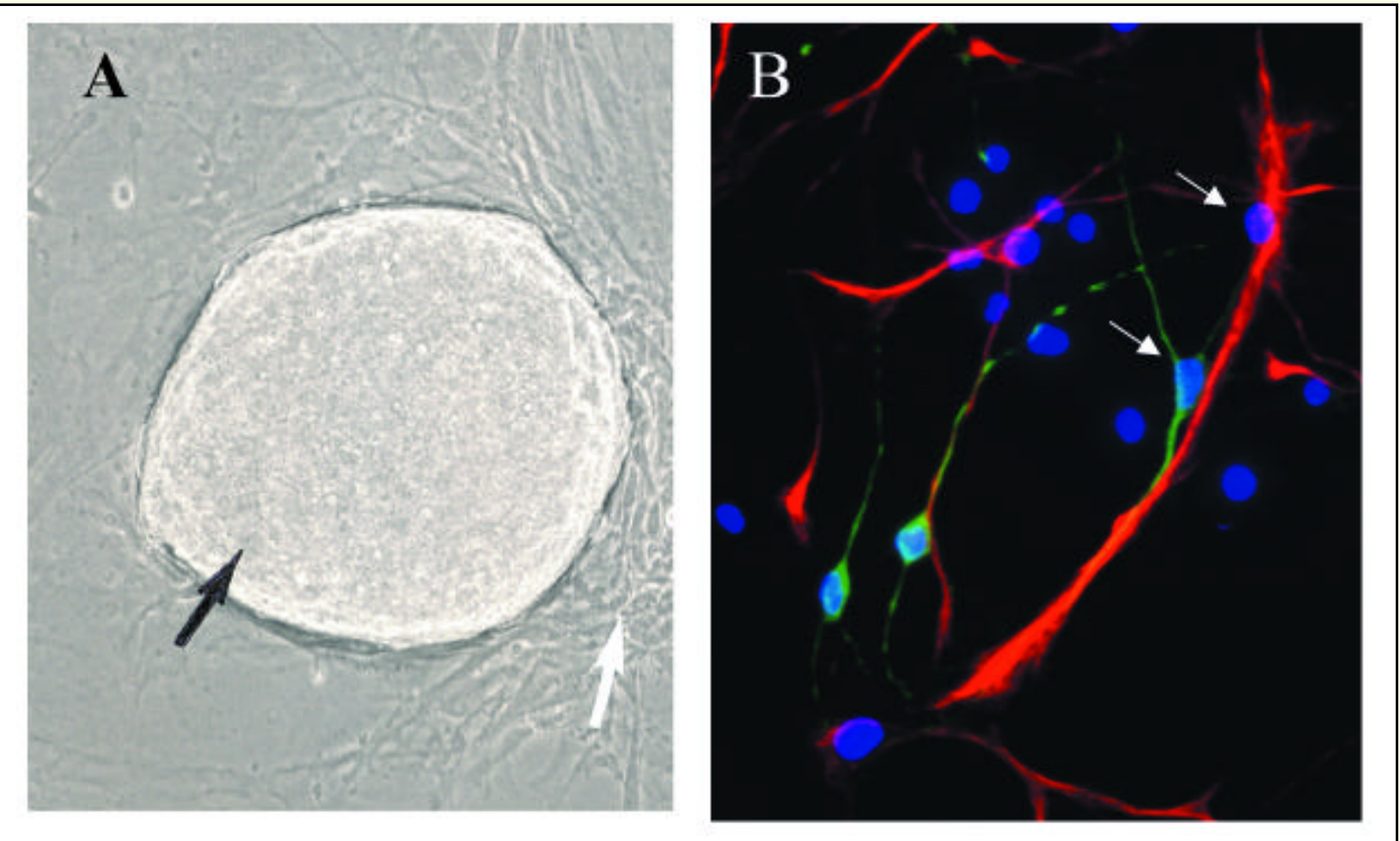

Figure 2. Mouse embryonic stem cells cultured in vitro can differentiate into various cells of the brain. (A) Mouse embryonic stem cells (black arrow) cultured on a feeder layer of fibroblasts (white arrow) differentiate into (B) astrocytes indicated by glial fibrillary acidic protein (GFAP) immunoreactivity (red) and neurons, as indicated by microtubule-associated protein 2 (MAP 2) immunoreactivity (green). Nuclei are counterstained with DAPI (blue). 


\section{DRUG DISCOVERY \\ AND GENOMIC TECHNOLOGIES}

deletion of the hypoxia-response element of VEGF in mice results in a surprising phenotype: progressive motor neuron deficits in adulthood. Most recently, a new gene linked to an early-onset, recessive, slowly progressing, and more rare form of ALS, juvenile ALS2, has been identified $(29,65)$. The gene encodes a putative guanine exchange factor for a $\mathrm{G}$ protein that currently is uncharacterized. Like SOD1, this gene is ubiquitously expressed. With the identification of new genes linked to the disease, the molecular events leading to cell death may become clearer. The discovery that at least four genes linked to Alzheimer's disease all affect amyloid precursor processing has made a major impact on drug discovery for Alzheimer's disease (58).

\section{CELLULAR THERAPIES FOR ALS AND NEURODEGENERATIVE DISEASES}

The discovery of small molecules that change the course of disease in ALS is most desirable and most likely to be developed by pharmaceutical companies; however, cellular therapies, either gene therapy or stem cell therapy, are being considered for neurodegenerative diseases. Failure of growth factors such as glial-derived neu- rotrophic factor (GDNF) and bone marrow-derived neurotrophic factor (BDNF) in the clinic has largely been attributed to the inability to deliver the proteins to the target cells. Gene therapy has provided an attractive alternative approach; however, good viral vectors and appropriate delivery methods have been key challenges to moving this field forward (19). Gene therapy approaches are currently being tested in animal models of $\operatorname{ALS}(2,33,62)$.

Stem cells, defined as "clonogenic, self-renewing progenitor cells that can generate one or more specialized cell types" (5), have been viewed with much excitement as a therapy for ALS and other neurodegenerative diseases. Both mouse (Figure 2A) and human embryonic stem cells when cultured in vitro in the appropriate conditions are able to differentiate into different cell types of the brain (Figure 2B). Other sources of stem cells such as bone marrow (11) and muscle (25) are being explored, but it remains controversial whether these stem cells will provide an abundant source of neurons. Neural cell replacement therapies are based on the idea that neurological function lost to injury or neurodegeneration can be improved by introducing new cells that can replace the function of lost neurons. In theory, new neurons could integrate into the host brain and form appropriate connections with relevant portions of 
the brain. In a disease such as ALS, it is hard to imagine that transplanted motor neurons would form appropriate connections with target muscles, where motor axons need to extend distances over a meter in length to reach the target. Alternatively, stem cells engineered to secrete growth factors or other factors required for neuronal survival can be introduced at the site of injury and may be a more feasible approach for ALS. Clearly, if this is to succeed, then early diagnosis is essential so that sufficient numbers of motor neurons are spared to maintain muscle function.

Another approach would be to stimulate endogenous stem cells in the brain to generate new neurons. Contrary to earlier beliefs, neurogenesis does occur in the adult nervous system, particularly in the hippocampus and olfactory bulb $(3,4)$. Studies to understand the molecular determinants and cues to stimulate endogenous stem cells are being undertaken $(16,24,43)$. Although promising, the field is only beginning to learn the potentials and challenges of these cells, especially for use in neurodegenerative diseases such as ALS.

With the availability of animal models that closely mimic human disease, an explosion of new technologies, and increasing knowledge about brain development and function, neurodegenerative research, although challenging, may yield a variety of new targets for the development of therapies. Understanding disease mechanism and identifying commonalities between the different neurodegenerative disorders will be invaluable in moving drug discovery for ALS forward.

\section{ACKNOWLEDGMENTS}

I would like to thank Corinne R. Greco for providing Figure 2.

\section{REFERENCES}

1.Al-Chalabi, A., P.M. Andersen, P. Nilsson, B. Chioza, J.L. Andersson, C. Russ, C.E. Shaw, J.F. Powell, and P.N. Leigh. 1999. Deletions of the heavy neurofilament subunit tail in amyotrophic lateral sclerosis. Hum. Mol. Genet. 8:157-164.

2.Alisky, J.M. and B.L. Davidson. 2000. Gene therapy for amyotrophic lateral sclerosis and other motor neuron diseases. Hum. Gene Ther. 11:2315-2329.

3.Alvarez-Buylla, A. 1992. Neurogenesis and plasticity in the CNS of adult birds. Exp. Neurol. 115:110-114

4.Alvarez-Buylla, A. and J.M. Garcia-Verdugo. 2002. Neurogenesis in adult subventricular zone. J. Neurosci. 22:629-634.

5.Anderson, D.J., F.H. Gage, and I.L. Weissman. 2001. Can stem cells cross lineage boundaries? Nat. Med. 7:393-395.

6.Bates, G.P., L. Mangiarini, A. Mahal, and S.W. Davies. 1997. Transgenic models of Huntington's disease. Hum. Mol. Genet. 6:1633-1637.

7.Beal, M.F. 1998. Mitochondrial dysfunction in neurodegenerative diseases. Biochim. Biophys. Acta 1366:211-223.

8.Beal, M.F. 2000. Mitochondria and the pathogenesis of ALS. Brain 123:1291-1292.

9.Beckman, J.S., M. Carson, C.D. Smith, and W.H. Koppenol. 1993. ALS, SOD and peroxynitrite. Nature 364:584.

10.Borchelt, D.R., M.K. Lee, H.S. Slunt, M. Guarnieri, Z.S. Xu, P.C. Wong, R.H. Brown, Jr., D.L. Price, et al. 1994. Superoxide dismutase 1 with mutations linked to familial amyotrophic lateral sclerosis possesses significant activity. Proc. Natl. Acad. Sci. USA 91:8292-
8296.

11.Brazelton, T.R., F.M. Rossi, G.I. Keshet, and H.M. Blau. 2000. From marrow to brain: expression of neuronal phenotypes in adult mice. Science 290:1775-1779.

12.Bruijn, L.I., M.F. Beal, M.W. Becher, J.B. Schulz, P.C. Wong, D.L. Price, and D.W. Cleveland. 1997. Elevated free nitrotyrosine levels, but not protein-bound nitrotyrosine or hydroxyl radicals, throughout amyotrophic lateral sclerosis (ALS)-like disease implicate tyrosine nitration as an aberrant in vivo property of one familial ALS-linked superoxide dismutase 1 mutant. Proc. Natl. Acad. Sci. USA 94:76067611.

13.Bruijn, L.I., M.W. Becher, M.K. Lee, K.L. Anderson, N.A. Jenkins, N.G. Copeland, S.S. Sisodia, J.D. Rothstein, et al. 1997. ALS-linked SOD1 mutant G85R mediates damage to astrocytes and promotes rapidly progressive disease with SOD1-containing inclusions. Neuron 18:327-338.

14.Bruijn, L.I. and D.W. Cleveland. 1996. Mechanisms of selective motor neuron death in ALS: insights from transgenic mouse models of motor neuron disease. Neuropathol. Appl. Neurobiol. 22:373-387.

15.Bruijn, L.I., M.K. Houseweart, S. Kato, K.L. Anderson, S.D. Anderson, E. Ohama, A.G. Reaume, R.W. Scott, and D.W. Cleveland. 1998. Aggregation and motor neuron toxicity of an ALS-linked SOD1 mutant independent from wild-type SOD1. Science 281:1851-1854.

16.Clarke, D.L., C.B. Johansson, J. Wilbertz, B. Veress, E. Nilsson, H. Karlstrom, U. Lendahl, and J. Frisen. 2000. Generalized potential of adult neural stem cells. Science 288:1660-1663.

17.Cleveland, D.W. and J.D. Rothstein. 2001. From Charcot to Lou Gehrig: deciphering selective motor neuron death in ALS. Nat. Rev. Neurosci. 2:806-819.

18.Conway, K.A., J.C. Rochet, R.M. Bieganski, and P.T. Lansbury, Jr. 2001. Kinetic stabilization of the $\alpha$-synuclein protofibril by a dopamine- $\alpha$-synuclein adduct. Science 294:1346-1349.

19.Costantini, L.C., J.C. Bakowska, X.O. Breakefield, and O. Isacson. 2000. Gene therapy in the CNS. Gene Ther. 7:93-109.

20.Cote, F., J.F. Collard, and J.P. Julien. 1993. Progressive neuronopathy in transgenic mice expressing the human neurofilament heavy gene: a mouse model of amyotrophic lateral sclerosis. Cell 73:35-46.

21.Davies, S.W., K. Beardsall, M. Turmaine, M. DiFiglia, N. Aronin, and G.P. Bates. 1998. Are neuronal intranuclear inclusions the com mon neuropathology of triplet-repeat disorders with polyglutamine-repeat expansions? Lancet 351:131-133.

22.Desnuelle, C., M. Dib, C. Garrel, and A. Favier. 2001. A doubleblind, placebo-controlled randomized clinical trial of $\alpha$-tocopherol (vitamin E) in the treatment of amyotrophic lateral sclerosis. ALS riluzole-tocopherol Study Group. Amyotroph Lateral Scler. Other Motor Neuron Disord. 2:9-18.

23.Friedlander, R.M., R.H. Brown, V. Gagliardini, J. Wang, and J. Yuan. 1997. Inhibition of ICE slows ALS in mice. Nature 388:31.

24.Gage, F.H. 2002. Neurogenesis in the adult brain. J. Neurosci. 22:612613

25.Goodell, M.A., K.A. Jackson, S.M. Majka, T. Mi, H. Wang, J. Pocius, C.J. Hartley, M.W. Majesky, et al. 2001. Stem cell plasticity in muscle and bone marrow. Ann. NY Acad. Sci. 938:208-220.

26.Gurney, M.E. 1994. Transgenic-mouse model of amyotrophic lateral sclerosis. N. Engl. J. Med. 331:1721-1722.

27.Gurney, M.E., F.B. Cutting, P. Zhai, A. Doble, C.P. Taylor, P.K. Andrus, and E.D. Hall. 1996. Benefit of vitamin E, riluzole, and gabapentin in a transgenic model of familial amyotrophic lateral sclerosis. Ann. Neurol. 39:147-157.

28.Gurney, M.E., T.J. Fleck, C.S. Himes, and E.D. Hall. 1998. Riluzole preserves motor function in a transgenic model of familial amyotrophic lateral sclerosis. Neurology 50:62-66.

29.Hadano, S., C.K. Hand, H. Osuga, Y. Yanagisawa, A. Otomo, R.S. Devon, N. Miyamoto, J. Showguchi-Miyata, et al. 2001. A gene encoding a putative GTPase regulator is mutated in familial amyotrophic lateral sclerosis 2. Nat. Genet. 29:166-173.

30.Higgins, C.M., C. Jung, H. Ding, and Z. Xu. 2002. Mutant Cu, Zn superoxide dismutase that causes motor neuron degeneration is present in mitochondria in the CNS. J. Neurosci. 22:RC215.

31.Hirano, A., H. Donnenfeld, S. Sasaki, and I. Nakano. 1984. Fine structural observations of neurofilamentous changes in amyotrophic lateral sclerosis. J. Neuropathol. Exp. Neurol. 43:461-470. 
32.Hirano, A., I. Nakano, L.T. Kurland, D.W. Mulder, P.W. Holley, and G. Saccomanno. 1984. Fine structural study of neurofibrillary changes in a family with amyotrophic lateral sclerosis. J. Neuropathol. Exp. Neurol. 43:471-480.

33.Hottinger, A.F., M. Azzouz, N. Deglon, P. Aebischer, and A.D. Zurn. 2000. Complete and long-term rescue of lesioned adult motoneurons by lentiviral-mediated expression of glial cell line-derived neurotrophic factor in the facial nucleus. J. Neurosci. 20:5587-5593.

34.Hottinger, A.F., E.G. Fine, M.E. Gurney, A.D. Zurn, and P. Aebischer. 1997. The copper chelator d-penicillamine delays onset of disease and extends survival in a transgenic mouse model of familial amyotrophic lateral sclerosis. Eur. J. Neurosci. 9:1548-1551.

35.Howland, D.S., J. Liu, Y. She, B. Goad, N.J. Maragakis, B. Kim, J. Erickson, J. Kulik, et al. 2002. Focal loss of the glutamate transporter EAAT2 in a transgenic rat model of SOD1 mutant-mediated amyotrophic lateral sclerosis (ALS). Proc. Natl. Acad. Sci. USA 99:16041609.

36.Hsiao, K. 1998. Transgenic mice expressing Alzheimer amyloid precursor proteins. Exp. Gerontol. 33:883-889.

37.Hurko, O. and F.S. Walsh. 2000. Novel drug development for amyotrophic lateral sclerosis. J. Neurol. Sci. 180:21-28.

38.Johnston, J.A., M.J. Dalton, M.E. Gurney, and R.R. Kopito. 2000. Formation of high molecular weight complexes of mutant $\mathrm{Cu}, \mathrm{Zn}$ - superoxide dismutase in a mouse model for familial amyotrophic lateral sclerosis. Proc. Natl. Acad. Sci. USA 97:12571-12576.

39.Julien, J.P. 2001. Amyotrophic lateral sclerosis. Unfolding the toxicity of the misfolded. Cell 104:581-591.

40. Klivenyi, P., R.J. Ferrante, R.T. Matthews, M.B. Bogdanov, A.M. Klein, O.A. Andreassen, G. Mueller, M. Wermer, et al. 1999. Neuroprotective effects of creatine in a transgenic animal model of amyotrophic lateral sclerosis. Nat. Med. 5:347-350.

41.Kong, J. and Z. Xu. 1998. Massive mitochondrial degeneration in motor neurons triggers the onset of amyotrophic lateral sclerosis in mice expressing a mutant SOD1. J. Neurosci. 18:3241-3250.

42.Li, M., V.O. Ona, C. Guegan, M. Chen, V. Jackson-Lewis, L.J. Andrews, A.J. Olszewski, P.E. Stieg, et al. 2000. Functional role of caspase- 1 and caspase- 3 in an ALS transgenic mouse model. Science 288:335-339.

43.Magavi, S.S. and J.D. Macklis. 2001. Manipulation of neural precursors in situ: induction of neurogenesis in the neocortex of adult mice. Neuropsychopharmacology 25:816-835.

44.Miller, R.G., J.P. Bouchard, P. Duquette, A. Eisen, D. Gelinas, Y. Harati, T.L. Munsat, L. Powe, et al. 1996. Clinical trials of riluzole in patients with ALS. ALS/Riluzole Study Group-II. Neurology 47:S86-S82.

45.Miller, R.G., R. Shepherd, H. Dao, A. Khramstov, M. Mendoza, J. Graves, and S. Smith. 1996. Controlled trial of nimodipine in amyotrophic lateral sclerosis. Neuromuscul. Disord. 6:101-104.

46.Miller, R.G., S.A. Smith, J.R. Murphy, J.R. Brinkmann, J. Graves, M. Mendoza, M.L. Sands, and S.P. Ringel. 1996. A clinical trial of verapamil in amyotrophic lateral sclerosis. Muscle Nerve 19:511-515.

47.Mulder, D.W., L.T. Kurland, K.P. Offord, and C.M. Beard. 1986. Familial adult motor neuron disease: amyotrophic lateral sclerosis. Neurology 36:511-517

48.Nguyen, M.D., R.C. Lariviere, and J.P. Julien. 2001. Deregulation of Cdk5 in a mouse model of ALS: toxicity alleviated by perikaryal neurofilament inclusions. Neuron 30:135-147.

49. Oosthuyse, B., L. Moons, E. Storkebaum, H. Beck, D. Nuyens, K. Brusselmans, J. Van Dorpe, P. Hellings, et al. 2001. Deletion of the hypoxia-response element in the vascular endothelial growth factor promoter causes motor neuron degeneration. Nat. Genet. 28:131-138.

50.Pasinelli, P., M.K. Houseweart, R.H. Brown, Jr., and D.W. Cleveland. 2000. Caspase-1 and -3 are sequentially activated in motor neuron death in $\mathrm{Cu}, \mathrm{Zn}$ superoxide dismutase-mediated familial amyotrophic lateral sclerosis. Proc. Natl. Acad. Sci. USA 97:13901-13906

51.Reaume, A.G., J.L. Elliott, E.K. Hoffman, N.W. Kowall, R.J. Ferrante, D.F. Siwek, H.M. Wilcox, D.G. Flood, et al. 1996. Motor neurons in $\mathrm{Cu} / \mathrm{Zn}$ superoxide dismutase-deficient mice develop normally but exhibit enhanced cell death after axonal injury. Nat. Genet. 13:43 47.

52. Reinholz, M.M., C.M. Merkle, and J.F. Poduslo. 1999. Therapeutic benefits of putrescine-modified catalase in a transgenic mouse mode of familial amyotrophic lateral sclerosis. Exp. Neurol. 159:204-216.

53.Ripps, M.E., G.W. Huntley, P.R. Hof, J.H. Morrison, and J.W. Gordon. 1995. Transgenic mice expressing an altered murine superoxide dismutase gene provide an animal model of amyotrophic lateral sclerosis. Proc. Natl. Acad. Sci. USA 92:689-693.

54. Rosen, D.R., T. Siddique, D. Patterson, D.A. Figlewicz, P. Sapp, A. Hentati, D. Donaldson, J. Goto, et al. 1993. Mutations in $\mathrm{Cu} / \mathrm{Zn}$ superoxide dismutase gene are associated with familial amyotrophic lateral sclerosis. Nature 362:59-62.

55.Rothstein, J.D., L.J. Martin, and R.W. Kuncl. 1992. Decreased glutamate transport by the brain and spinal cord in amyotrophic lateral sclerosis. N. Engl. J. Med. 326:1464-1468

56. Rothstein, J.D., G. Tsai, R.W. Kuncl, L. Clawson, D.R. Cornblath, D.B. Drachman, A. Pestronk, B.L. Stauch, and J.T. Coyle. 1990. Abnormal excitatory amino acid metabolism in amyotrophic lateral sclerosis. Ann. Neurol. 28:18-25.

57.Scott, H.L., D.V. Pow, A.E. Tannenberg, and P.R. Dodd. 2002. Aberrant expression of the glutamate transporter excitatory amino acid transporter 1 (EAAT1) in Alzheimer's disease. J. Neurosci. 22:RC206.

58.Selkoe, D.J. 2001. Presenilin, Notch, and the genesis and treatment of Alzheimer's disease. Proc. Natl. Acad. Sci. USA 98:11039-11041.

59.Steffan, J.S., L. Bodai, J. Pallos, M. Poelman, A. McCampbell, B.L. Apostol, A. Kazantsev, E. Schmidt, et al. 2001. Histone deacetylase inhibitors arrest polyglutamine-dependent neurodegeneration in Drosophila. Nature 413:739-743.

60.Subramaniam, J.R., W.E. Lyons, J. Liu, T.B. Bartnikas, J. Rothstein, D.L. Price, D.W. Cleveland, J.D. Gitlin, and P.C. Wong. 2002. Mutant SOD1 causes motor neuron disease independent of copper chaperone-mediated copper loading. Nat. Neurosci. 11:11.

61.Wang, J., G. Xu, and R. Borchelt David. 2002. High molecular weight complexes of mutant superoxide dismutase 1: age-dependent and tissue-specific accumulation, p. 139-148. In Neurobiology of Disease. Elsevier Science, New York.

62.Watabe, K., T. Sakamoto, T. Ohashi, Y. Kawazoe, K. Oyanagi, T. Takeshima, K. Inoue, Y. Eto, and S.U. Kim. 2001. Adenoviral gene transfer of glial cell line-derived neurotrophic factor to injured adult motoneurons. Hum. Cell 14:7-15.

63. Wong, P.C., C.A. Pardo, D.R. Borchelt, M.K. Lee, N.G. Copeland, N.A. Jenkins, S.S. Sisodia, D.W. Cleveland, and D.L. Price. 1995. An adverse property of a familial ALS-linked SOD1 mutation causes motor neuron disease characterized by vacuolar degeneration of mitochondria. Neuron 14:1105-1116.

64. Yamamoto, M., Y. Kobayashi, M. Li, H. Niwa, N. Mitsuma, Y. Ito, T. Muramatsu, and G. Sobue. 2001. In vivo gene electroporation of glial cell line-derived neurotrophic factor (GDNF) into skeletal muscle of SOD1 mutant mice. Neurochem. Res. 26:1201-1207.

65. Yang, Y., A. Hentati, H.X. Deng, O. Dabbagh, T. Sasaki, M. Hirano, W.Y. Hung, K. Ouahchi, et al. 2001. The gene encoding alsin, a protein with three guanine-nucleotide exchange factor domains, is mutated in a form of recessive amyotrophic lateral sclerosis. Nat. Genet. 29:160-165.

66. Yasojima, K., W.W. Tourtellotte, E.G. McGeer, and P.L. McGeer. 2001. Marked increase in cyclooxygenase- 2 in ALS spinal cord: implications for therapy. Neurology 57:952-956.

67.Zhang, Y., V.L. Dawson and T.M. Dawson. 2000. Oxidative stress and genetics in the pathogenesis of Parkinson's disease. Neurobiol. Dis. 7:240-250.

Address correspondence to Dr. Lucie I. Bruijn, Office of the Science Director, The Amyotrophic Lateral Sclerosis Association, 246 Goose Lane, Suite 106 Innovation Park, Guilford, CT 06437, USA.e-mail: lbruijn@snet.net (www.alsa.org)

Feedback and suggestions for contributions to the "Drug Discovery and Genomic Technologies" section are welcomed by the Scientific Editor, Dr. James Ellingboe(ellingboe@BioTechniques.com). 